\title{
STUDY RANCANGAN SUMUR RESAPAN AIR HUJAN UNTUK MENGATASI GENANGAN AIR PADA PERUMAHAN MONCONGLOE KABUPATEN MAROS
}

\author{
Eris Nur Dirman ${ }^{1)}$ \\ ${ }^{1)}$ Dosen Program Studi Teknik Sipil, Sekolah Tinggi Teknik Baramuli, Pinrang \\ 1) erisnurdirman@gmail.com
}

\begin{abstract}
Abstrak
Penelitian ini bertujuan untuk merancang sumur resapan yang optimum yang dapat mencegah terjadingan genangan air pada perumahan moncongloe, Kabupaten Maros. Metode penelitian yang digunakan ialah metode kualitatif kuantitatif dengan Teknik pengumpulan data menggunakan metode wawancara, survei, dokumentasi dan studi pustaka. Perancangan sumur resapan dilakukan dengan memperhitungkan intensitas hujan yang dianalisis dengan menggunakan rumus Mononobe dan perhitungan kedalaman sumur resapan optimum dilakukan dengan menggunakan Metode Sunjoto. Pada penelitian ini juga dilakukan pengujian laboratorium dengan pengujian koefisien permeabilitas tanah untuk mengetahui besarnya daya resap tanah. Hasil penelitian menunjukkan bahwa untuk pembuatan sumur resapan pada daerah penelitian yaitu pada daerah perumahan Moncongloe diperoleh debit yang dapat diresapkan untuk rumah tipe 36/90 dengan jumlah penghuni 5 orang, maka debit yang diresapkan $0.000581488 \mathrm{~m} 3 /$ detik dan kedalaman sumurnya adalah $1 \mathrm{~m}$ dan untuk rumah tipe 45/90 dengan jumlah penghuni 5 orang, debit yang diresapkan adalah $0.000725558 \mathrm{~m} 3 /$ detik dan kedalaman sumurnya adalah $1 \mathrm{~m}$.
\end{abstract}

Kata kunci : Genangan air, sumur resapan, rumus mononobe, infiltrasi.

\section{PENDAHULUAN}

Air merupakan salah satu sumber daya yang sangat penting bagi kehidupan manusia, terlebih bagi bangsa Indonesia yang mempunyai laju pertumbuhan penduduk cukup tinggi. Perkembangan pembangunan pemukiman penduduk khususnya di kotakota besar dewasa ini semakin meningkat. Sejalan dengan meningkatnya laju pertumbuhan penduduk dan tingkat urbanisasi yang tinggi, kebutuhan pemukiman di kota besar menjadi prioritas penting dalam pengembangan kota. Kawasan yang dulu merupakan lahan pertanian atau ladang banyak yang sudah berubah menjadi pemukiman elit.

Berbagai dampak dapat ditimbulkan akibat pengembangan kawasan perkotaan ini. Dampak positifnya adalah kemajuan perekonomian penduduk dan perluasan pembangunan. Namun pada sisi lainnya memberikan dampak negatif bagi konservasi air tanah, yaitu akan mengurangi areal resapan air hujan ke dalam tanah. Sementara penyerapan air tanah berlangsung terus dengan intensitas yang semakin besar maka akan terjadi penurunan muka air tanah.

Penutupan permukaan tanah oleh adanya pembangunan sarana dan fasilitas pemukiman juga dapat mengakibatkan terjadinya genangan - genangan pada saat hujan karena fungsi resapan yang semakin berkurang. Bila tidak dilakukan konservasi muka air tanah secara benar, diperkirakan pada masa mendatang akan kesulitan untuk mendapatkan air tanah. Oleh karena itu pembangunan pengembangan kota dan kepentingan industri seharusnya memperhatikan aspek konservasi air tanah. Berbagai cara dapat dilakukan untuk konservasi air tanah, diantaranya adalah dengan mengguanakan sumur resapan yang berfungsi untuk mengurangi besarnya aliran permukaan tanah, memperbesar penyerapan air ke dalam tanah ( untuk pengisian air 
tanah/recharge ) serta memperkecil fluktuasi debit air. Sumur resapan merupakan teknologi yang ramah lingkungan karena dapat dikembangkan tanpa mengganggu fungsi - fungsi sistem lainnya. Sebagai contoh pada kawasan pemukiman penggunaan sumur resapan ini tidak akan mengganggu keindahan kawasan hunian dan dapat mengurangi masalah genangan air.

Perencanaan sumur resapan dianjurkan menggunakan prinsip-prinsip antara lain mampu menampung volume air hujan untuk diresapkan kedalam tanah, semakin cepat meresap semakin baik serta dapat menjaga ketersediaan cadangan air tanah dikala musim kemarau datang. Selain itu dalam perencanaan sumur resapan, sebaiknya dapat menghasilkan debit resapan maksimum.

Berdasarkan latar belakang tersebut, penulis tertarik untuk melakukan penelitian dengan judul "Study Rancangan Sumur Resapan Air Hujan Untuk Mengatasi Genangan Air pada Perumahan Moncongloe Kabupaten Maros".

\section{METODOLOGI PENELITIAN}

Penelitian ini dilaksanakan di Perumahan Moncongloe, Kabupaten Maros. Perencanaan sumur resapan juga tidak terlepas dari kondisi tanah di sekitarnya, karena konstruksi sumur resapan ini secara langsung akan berhubungan dengan lapisan tanah. Lapisan tanah inilah yang sebetulnya akan menentukan kemampuan sumur dalam meresapkan air, maka dalam perencanaan sumur resapan harus memperhatikan sifatsifat fisik tanah seperti kemampuan rembesan tanah.

Objek yang diamati dalam penelitian ini adalah debit gabungan antara intensitas hujan dan debit air kotor yang dihasilkan dari masing-masing rumah, kemampuan resap sumur untuk memperkecil nilai koefisien limpasan. Variabel-variabel yang diperlukan dalam penelitian ini yaitu sebagai berikut : (1)Luasan permukaan penutupan, yaitu lahan yang airnya akan ditampung dalam sumur resapan, yakni luasan tanah pada tiap tipe rumah, (2)Karakteristik hujan, meliputi intensitas hujan,dan (3)Koefisien permeabilitas tanah. 


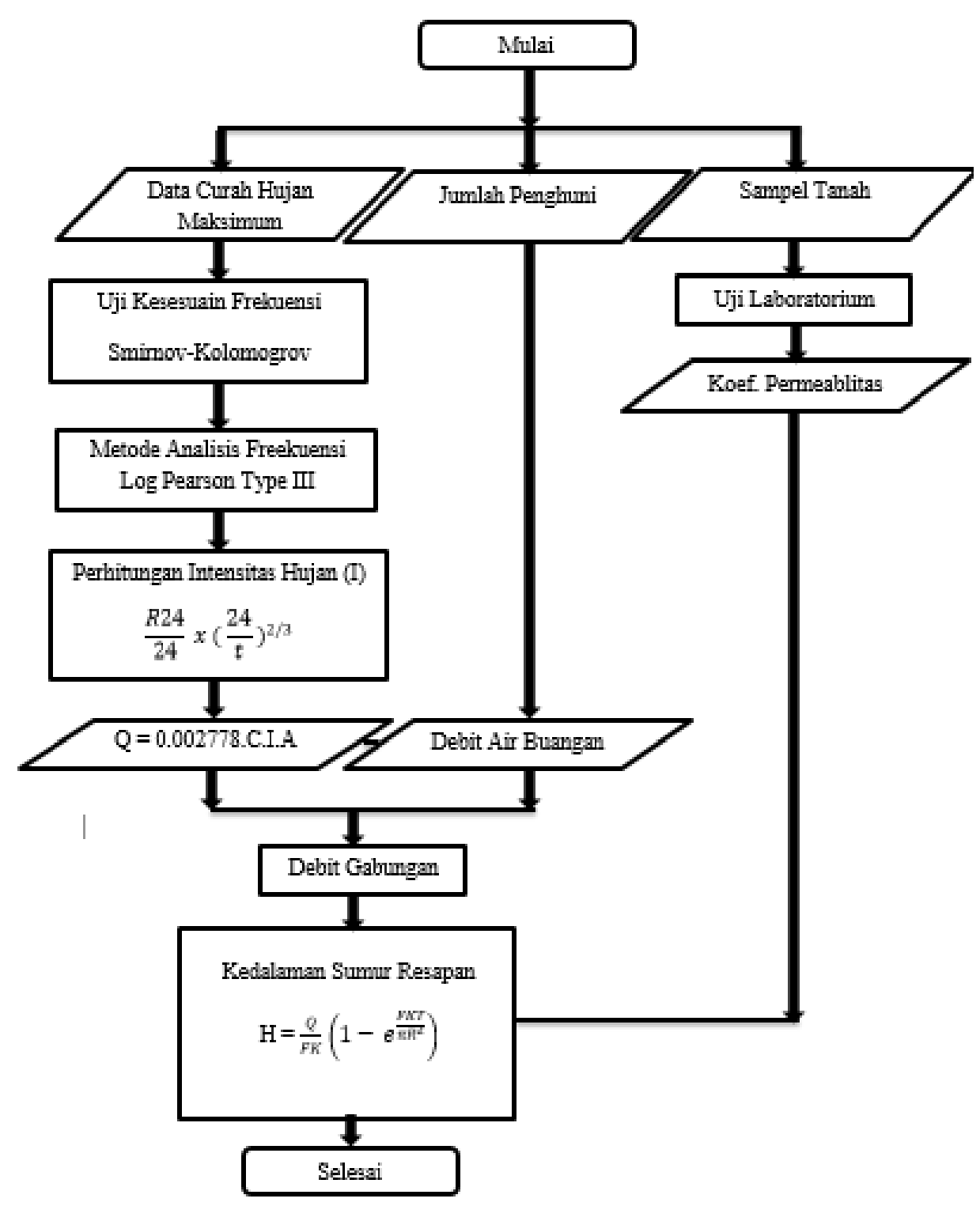

Gambar 1. Diagram Alir Penelitian

\section{HASIL DAN PEMBAHASAN}

Berdasarkan analisis data primer dan sekuder, diperoleh hasil antara lain :

Intensitas Hujan pada Durasi 315 menit - 360 menit

Berdasarkan data curah hujan, maka diperoleh hasil perhitungan intensitas curah hujan dengan menggunakan persamaam Mononobe sebagai berikut:

$\mathrm{I}=\frac{R 24}{24} x\left(\frac{24}{t}\right)^{2 / 3}$

$\mathrm{I}=$ Intensitas hujan $(\mathrm{mm} / \mathrm{jam})$

$\mathrm{t}=$ Lamanya Hujan (jam)

$\mathrm{R}_{24}=$ curah hujan maksimum harian selama 24 jam (mm) 
Hasil perhitungan intensitas curah hujan pada durasi 315 menit - 360 menit disajikan pada tabel berikut :

Tabel 1. Hasil Perhitungan Intensitas Curah Hujan Durasi 315 menit - 360 menit

\begin{tabular}{ccccccc}
\hline \multirow{2}{*}{$\begin{array}{c}\text { Durasi } \\
\text { menit) }\end{array}$} & \multicolumn{7}{c}{ Intensitas Curah Hujan (mm/jam) } \\
\cline { 2 - 7 } & $\mathbf{2}$ & $\mathbf{5}$ & $\mathbf{1 0}$ & $\mathbf{2 5}$ & $\mathbf{5 0}$ & $\mathbf{1 0 0}$ \\
\hline 315 & 15.86633 & 20.08013 & 22.39116 & 24.89726 & 26.52037 & 27.97091 \\
\hline 320 & 15.70063 & 19.87042 & 22.15731 & 24.63723 & 26.24339 & 27.67878 \\
\hline 325 & 15.53918 & 19.66609 & 21.92946 & 24.38389 & 25.97353 & 27.39416 \\
\hline 330 & 15.38182 & 19.46694 & 21.70739 & 24.13696 & 25.71050 & 27.11675 \\
\hline 335 & 15.22838 & 19.27275 & 21.49085 & 23.89619 & 25.45404 & 26.84625 \\
\hline 340 & 15.07871 & 19.08333 & 21.27964 & 23.66133 & 25.20387 & 26.58240 \\
\hline 345 & 14.93267 & 18.89850 & 21.07354 & 23.43217 & 24.95976 & 26.32494 \\
\hline 350 & 14.79011 & 18.71809 & 20.87235 & 23.20847 & 24.72148 & 26.07363 \\
\hline 355 & 14.65091 & 18.54191 & 20.67591 & 22.99003 & 24.48880 & 25.82822 \\
\hline 360 & 14.51494 & 18.36983 & 20.48401 & 22.77666 & 24.26152 & 25.58852 \\
\hline Koefinyyyyyyyyyyy
\end{tabular}

\section{Koefisien Permeabilitas Tanah}

Tanah sebagai media peresap memiliki arti penting dalam perencanaan sumur resapan. Karena proses pengisian air pada sumur akan mengalami peresapan akibat pengaruh gravitasi bumi. Oleh karena itu sifat fisik tanah merupakan parameter utama dalam perencanaan, sifat fisik ini ditunjukkan oleh koefisien permeabilitas.

Proses peresapan tergantung dari sifat fisik tanah dengan indikator adalah nilai koefisien permeabilitas tanah $(\mathrm{K})$, karena proses peresapan adalah proses mengalirnya air melalui pori-pori dalam tanah sehingga semakin besar pori tanah semakin besar pula nilai k akibatnya akan semakin cepat pula daya resapnya. Semakin kecil nilai $\mathrm{K}$ maka akan semakin besar dimensi sumur yang diperlukan. Berikut adalah hasil perhitungan koefisien permeabilitas tanah di perumahan Moncongloe :

Tabel 2. Hasil Perhitungan Koefisien Permeabilitas (m/detik)

\begin{tabular}{cccccc}
\hline No. & Titik & \multicolumn{2}{c}{ Koefisien Permeabilitas (cm/detik) } & $\begin{array}{c}\text { Rata-rata } \\
\text { (cm/detik) }\end{array}$ & $\begin{array}{c}\text { Rata-rata } \\
\text { (m/detik) }\end{array}$ \\
\cline { 3 - 4 } & & $\begin{array}{c}\text { Kedalaman 50 } \\
\text { cm }\end{array}$ & $\begin{array}{c}\text { Kedalaman 100 } \\
\text { cm }\end{array}$ & & \\
\hline 1 & I & $2,45026 \times 10^{-5}$ & $6,66783 \times 10^{-6}$ & $1,55852 \times 10^{-5}$ & $1,55852 \times 10^{-7}$ \\
\hline 2 & II & $2,12514 \times 10^{-5}$ & $2,00061 \times 10^{-5}$ & $2,06287 \times 10^{-5}$ & $2,06287 \times 10^{-7}$ \\
\hline 3 & III & $2,12514 \times 10^{-5}$ & $9,69881 \times 10^{-6}$ & $1,48619 \times 10^{-5}$ & $1,48619 \times 10^{-7}$ \\
\hline
\end{tabular}

Berdasarkan hasil perhitungan koefisien permeabilitas tanah di atas, maka jenis tanah pada lokasi penelitian di Perumahan Moncongloe adalah lempung (clay) dan lanau (silt).

\section{Perancangan Sumur Resapan}

Perancangan sumur resapan dilakukan dengan terlebih dahulu melakukan perhitungan dedit. Metode untuk penentuan debit yang umum dipakai adalah metode Rasional USSCS (1973). (Goldman et.al.,1986)

Persamaan matematik metode Rasional :

$\mathrm{Q}=0,002778$. C.I.A

$\mathrm{Q}=\operatorname{debit}\left(\mathrm{m}^{3} / \mathrm{dt}\right)$ 
$\mathrm{C}=$ koefisien pengaliran permukaan $(<1)$

I = intensitas hujan ( $\mathrm{mm} / \mathrm{jam})$

A = luas bidang tangkapan hujan $\left(\mathrm{m}^{2}\right)$

Berikut adalah hasil perhitungan debit tiap tipe rumah di perumahan Moncongloe:

Tabel 3. Hasil Perhitungan Debit Tiap Tipe rumah

\begin{tabular}{|c|c|c|}
\hline \multirow{2}{*}{$\begin{array}{l}\text { Durasi } \\
\text { (menit) }\end{array}$} & \multicolumn{2}{|c|}{ Debit (Q) Maksimal (m³/detik) } \\
\hline & Tipe 36/90 & Tipe $45 / 90$ \\
\hline 315 & 0.000190777 & 0.000238471 \\
\hline 320 & 0.000188784 & 0.000235980 \\
\hline 325 & 0.000186843 & 0.000233553 \\
\hline 330 & 0.000184951 & 0.000231188 \\
\hline 335 & 0.000183106 & 0.000228882 \\
\hline 340 & 0.000181306 & 0.000226633 \\
\hline 345 & 0.000179550 & 0.000224438 \\
\hline 350 & 0.000177836 & 0.000222295 \\
\hline 355 & 0.000176162 & 0.000220203 \\
\hline 360 & 0.000174527 & 0.000218159 \\
\hline
\end{tabular}

Tabel 4. Hasil Perhitungan Debit Air Gabungan Tipe 36/90 ( $\left.\mathrm{m}^{3} / \mathrm{detik}\right)$

\begin{tabular}{|c|c|c|c|c|}
\hline $\begin{array}{l}\text { Durasi } \\
\text { (menit) }\end{array}$ & $\begin{array}{c}\text { Q Maksimal } \\
\left(\mathbf{m}^{3} / \text { detik }\right)\end{array}$ & $\begin{array}{c}\text { Jumlah } \\
\text { Penghuni } \\
\text { (Org) }\end{array}$ & $\begin{array}{c}\text { Debit Air } \\
\text { Kotor } \\
\left(\mathbf{m}^{3} / \text { detik }\right)\end{array}$ & $\begin{array}{c}\text { Debit } \\
\text { Gabungan } \\
\left(\mathrm{m}^{3} / \text { detik) }\right.\end{array}$ \\
\hline \multirow[t]{5}{*}{315} & 0.000190777 & 5 & 0.000005208 & 0.000195985 \\
\hline & & 4 & 0.000004166 & 0.000194943 \\
\hline & & 3 & 0.000003125 & 0.000193902 \\
\hline & & 2 & 0.000002083 & 0.000192860 \\
\hline & & 1 & 0.000001041 & 0.000191818 \\
\hline \multirow[t]{5}{*}{320} & 0.000188784 & 5 & 0.000005208 & 0.000193992 \\
\hline & & 4 & 0.000004166 & 0.000192950 \\
\hline & & 3 & 0.000003125 & 0.000191909 \\
\hline & & 2 & 0.000002083 & 0.000190867 \\
\hline & & 1 & 0.000001041 & 0.000189825 \\
\hline \multirow[t]{5}{*}{325} & 0.000186843 & 5 & 0.000005208 & 0.000192051 \\
\hline & & 4 & 0.000004166 & 0.000191009 \\
\hline & & 3 & 0.000003125 & 0.000189968 \\
\hline & & 2 & 0.000002083 & 0.000188926 \\
\hline & & 1 & 0.000001041 & 0.000187884 \\
\hline \multirow[t]{5}{*}{330} & 0.000184951 & 5 & 0.000005208 & 0.000190159 \\
\hline & & 4 & 0.000004166 & 0.000189117 \\
\hline & & 3 & 0.000003125 & 0.000188076 \\
\hline & & 2 & 0.000002083 & 0.000187034 \\
\hline & & 1 & 0.000001041 & 0.000185992 \\
\hline 335 & 0.000183106 & 5 & 0.000005208 & 0.000188314 \\
\hline
\end{tabular}




\begin{tabular}{|c|c|c|c|c|}
\hline $\begin{array}{l}\text { Durasi } \\
\text { (menit) }\end{array}$ & $\begin{array}{c}\text { Q Maksimal } \\
\text { (m³/detik) }\end{array}$ & $\begin{array}{c}\text { Jumlah } \\
\text { Penghuni } \\
\text { (Org) }\end{array}$ & $\begin{array}{l}\text { Debit Air } \\
\text { Kotor } \\
\text { (m³/detik) }\end{array}$ & $\begin{array}{c}\text { Debit } \\
\text { Gabungan } \\
\left(\mathrm{m}^{3} / \text { detik) }\right.\end{array}$ \\
\hline & & 4 & 0.000004166 & 0.000187272 \\
\hline & & 3 & 0.000003125 & 0.000186231 \\
\hline & & 2 & 0.000002083 & 0.000185189 \\
\hline & & 1 & 0.000001041 & 0.000184147 \\
\hline \multirow[t]{5}{*}{340} & 0.000181306 & 5 & 0.000005208 & 0.000186514 \\
\hline & & 4 & 0.000004166 & 0.000185472 \\
\hline & & 3 & 0.000003125 & 0.000184431 \\
\hline & & 2 & 0.000002083 & 0.000183389 \\
\hline & & 1 & 0.000001041 & 0.000182347 \\
\hline \multirow[t]{5}{*}{345} & 0.00017955 & 5 & 0.000005208 & 0.000184758 \\
\hline & & 4 & 0.000004166 & 0.000183716 \\
\hline & & 3 & 0.000003125 & 0.000182675 \\
\hline & & 2 & 0.000002083 & 0.000181633 \\
\hline & & 1 & 0.000001041 & 0.000180591 \\
\hline \multirow[t]{5}{*}{350} & 0.000177836 & 5 & 0.000005208 & 0.000183044 \\
\hline & & 4 & 0.000004166 & 0.000182002 \\
\hline & & 3 & 0.000003125 & 0.000180961 \\
\hline & & 2 & 0.000002083 & 0.000179919 \\
\hline & & 1 & 0.000001041 & 0.000178877 \\
\hline \multirow[t]{5}{*}{355} & 0.000176162 & 5 & 0.000005208 & 0.000181370 \\
\hline & & 4 & 0.000004166 & 0.000180328 \\
\hline & & 3 & 0.000003125 & 0.000179287 \\
\hline & & 2 & 0.000002083 & 0.000178245 \\
\hline & & 1 & 0.000001041 & 0.000177203 \\
\hline \multirow[t]{5}{*}{360} & 0.000174527 & 5 & 0.000005208 & 0.000179735 \\
\hline & & 4 & 0.000004166 & 0.000178693 \\
\hline & & 3 & 0.000003125 & 0.000177652 \\
\hline & & 2 & 0.000002083 & 0.000176610 \\
\hline & & 1 & 0.000001041 & 0.000175568 \\
\hline
\end{tabular}

Tabel 5. Hasil Perhitungan Debit Air Gabungan Tipe 45/90 ( $\mathrm{m}^{3} /$ detik)

\begin{tabular}{ccccc}
\hline $\begin{array}{c}\text { Durasi } \\
(\text { menit })\end{array}$ & $\begin{array}{c}\text { Q Maksimal } \\
\left(\mathbf{m}^{3} / \text { detik }\right)\end{array}$ & $\begin{array}{c}\text { Jumlah } \\
\text { Penghuni } \\
(\text { Org })\end{array}$ & $\begin{array}{c}\text { Debit Air } \\
\text { Kotor } \\
\left(\mathbf{m}^{3} / \mathbf{d e t i k}\right)\end{array}$ & $\begin{array}{c}\text { Debit } \\
\text { Gabungan } \\
\left(\mathbf{m}^{3} / \mathbf{d e t i k}\right)\end{array}$ \\
\hline $\mathbf{3 1 5}$ & 0.000238471 & 5 & 0.000005208 & 0.000243679 \\
\hline & 4 & 0.000004166 & 0.000242637 \\
\hline & 3 & 0.000003125 & 0.000241596 \\
\hline $\mathbf{3 2 0}$ & 0.00023598 & 2 & 0.000002083 & 0.000240554 \\
\hline & 1 & 0.000001041 & 0.000239512 \\
\hline & 5 & 0.000005208 & 0.000241188 \\
\hline & 4 & 0.000004166 & 0.000240146 \\
\hline & 3 & 0.000003125 & 0.000239105 \\
\hline & 2 & 0.000002083 & 0.000238063 \\
\hline
\end{tabular}




\begin{tabular}{|c|c|c|c|c|}
\hline $\begin{array}{l}\text { Durasi } \\
\text { (menit) }\end{array}$ & $\begin{array}{c}\text { Q Maksimal } \\
\text { (m³/detik) }\end{array}$ & $\begin{array}{c}\text { Jumlah } \\
\text { Penghuni } \\
\text { (Org) }\end{array}$ & $\begin{array}{c}\text { Debit Air } \\
\text { Kotor } \\
\left(\mathbf{m}^{3} / \text { detik }\right)\end{array}$ & $\begin{array}{c}\text { Debit } \\
\text { Gabungan } \\
\left(\mathrm{m}^{3} / \text { detik }\right)\end{array}$ \\
\hline \multirow[t]{5}{*}{325} & 0.000233553 & 5 & 0.000005208 & 0.000238761 \\
\hline & & 4 & 0.000004166 & 0.000237719 \\
\hline & & 3 & 0.000003125 & 0.000236678 \\
\hline & & 2 & 0.000002083 & 0.000235636 \\
\hline & & 1 & 0.000001041 & 0.000234594 \\
\hline \multirow[t]{5}{*}{330} & 0.000231188 & 5 & 0.000005208 & 0.000236396 \\
\hline & & 4 & 0.000004166 & 0.000235354 \\
\hline & & 3 & 0.000003125 & 0.000234313 \\
\hline & & 2 & 0.000002083 & 0.000233271 \\
\hline & & 1 & 0.000001041 & 0.000232229 \\
\hline \multirow[t]{5}{*}{335} & 0.000228882 & 5 & 0.000005208 & 0.000234090 \\
\hline & & 4 & 0.000004166 & 0.000233048 \\
\hline & & 3 & 0.000003125 & 0.000232007 \\
\hline & & 2 & 0.000002083 & 0.000230965 \\
\hline & & 1 & 0.000001041 & 0.000229923 \\
\hline \multirow[t]{5}{*}{340} & 0.000226633 & 5 & 0.000005208 & 0.000231841 \\
\hline & & 4 & 0.000004166 & 0.000230799 \\
\hline & & 3 & 0.000003125 & 0.000229758 \\
\hline & & 2 & 0.000002083 & 0.000228716 \\
\hline & & 1 & 0.000001041 & 0.000227674 \\
\hline \multirow[t]{5}{*}{345} & 0.000224438 & 5 & 0.000005208 & 0.000229646 \\
\hline & & 4 & 0.000004166 & 0.000228604 \\
\hline & & 3 & 0.000003125 & 0.000227563 \\
\hline & & 2 & 0.000002083 & 0.000226521 \\
\hline & & 1 & 0.000001041 & 0.000225479 \\
\hline \multirow[t]{5}{*}{350} & 0.000222295 & 5 & 0.000005208 & 0.000227503 \\
\hline & & 4 & 0.000004166 & 0.000226461 \\
\hline & & 3 & 0.000003125 & 0.000225420 \\
\hline & & 2 & 0.000002083 & 0.000224378 \\
\hline & & 1 & 0.000001041 & 0.000223336 \\
\hline \multirow[t]{5}{*}{355} & 0.000220203 & 5 & 0.000005208 & 0.000225411 \\
\hline & & 4 & 0.000004166 & 0.000224369 \\
\hline & & 3 & 0.000003125 & 0.000223328 \\
\hline & & 2 & 0.000002083 & 0.000222286 \\
\hline & & 1 & 0.000001041 & 0.000221244 \\
\hline \multirow[t]{5}{*}{360} & 0.000218159 & 5 & 0.000005208 & 0.000223367 \\
\hline & & 4 & 0.000004166 & 0.000222325 \\
\hline & & 3 & 0.000003125 & 0.000221284 \\
\hline & & 2 & 0.000002083 & 0.000220242 \\
\hline & & 1 & 0.000001041 & 0.000219200 \\
\hline
\end{tabular}

Setelah dilakukan perhitungan debit, maka dalam perencangan dilakukan perhitungan kedalaman sumur resapan.Perhitungan kedalaman sumur resapan untuk tipe 36/90 dengan jumlah penghuni 5 orang dilakukan sebagai berikut: 


$$
\begin{aligned}
& \mathrm{H}=\frac{Q}{f K}\left(1-e^{-\frac{f K T}{\pi R^{2}}}\right) \\
& =\frac{0,000581488}{6,28 \times 1,4862 \times 10^{-7}}\left(1-e^{-\frac{6,28 \times 1,4862 \times 10^{7} \times 3600}{3,14 \times 1^{2}}}\right) \\
& =0.666 \mathrm{~m}=1.00 \mathrm{~m}
\end{aligned}
$$

Tabel berikut menyajikan hasil perhitungan kedalaman sumur resapan untuk tiap

\begin{tabular}{|c|c|c|c|c|c|c|c|c|}
\hline Type & Kala & Waktu & $\begin{array}{c}\text { Koefisien } \\
\text { Permeabilitas }\end{array}$ & $\mathbf{R}$ & $\mathbf{f}$ & $\begin{array}{c}\mathbf{Q} \\
\text { gabungan }\end{array}$ & $\mathbf{H}$ & $\mathbf{H}$ \\
\hline Rumah & Ulang & (T) & $(\mathbf{K})$ & & & & & \\
\hline$\left(\mathbf{m}^{2}\right)$ & (Tahun) & (detik) & (m/detik) & (m) & (m) & (m³/detik) & (m) & (m) \\
\hline $36 / 90$ & 5 & 3600 & 1.48619E-07 & 1 & 6.28 & 0.000581488 & 0.666 & 1.00 \\
\hline $45 / 90$ & 5 & 3600 & 1.48619E-07 & 1 & 6.28 & 0.000725558 & 0.831 & 1.00 \\
\hline
\end{tabular}
tipe rumah.

Tabel 6. Hasil Perhitungan Kedalaman Sumur Resapan (m)

Pembahasan

Berdasarkan hasil analisis, maka koefisien permeabilitas yang dipakai untuk merencanakan adalah koefisien permeabilitas yang paling kecil yaitu pada titik 3 ( $\left.1,4862 \times 10^{-7}\right)$.

Hasil penelitian menunjukkan bahwa untuk pembuatan sumur resapan pada daerah penelitian yaitu pada daerah perumahan Moncongloe diperoleh debit yang dapat diresapkan untuk rumah type 36/90 dengan jumlah penghuni 5 orang, maka debit yang diresapkan $0.000581488 \mathrm{~m} 3 /$ detik dan kedalaman sumurnya adalah $1 \mathrm{~m}$ dan untuk rumah type 45/90 dengan jumlah penghuni 5 orang, debit yang diresapkan adalah $0.000725558 \mathrm{~m} 3 /$ detik dan kedalaman sumurnya adalah $1 \mathrm{~m}$. Berikut ditampilkan gambar denah letak sumur resapan dan detail sumur resapan hasil rancangan. 


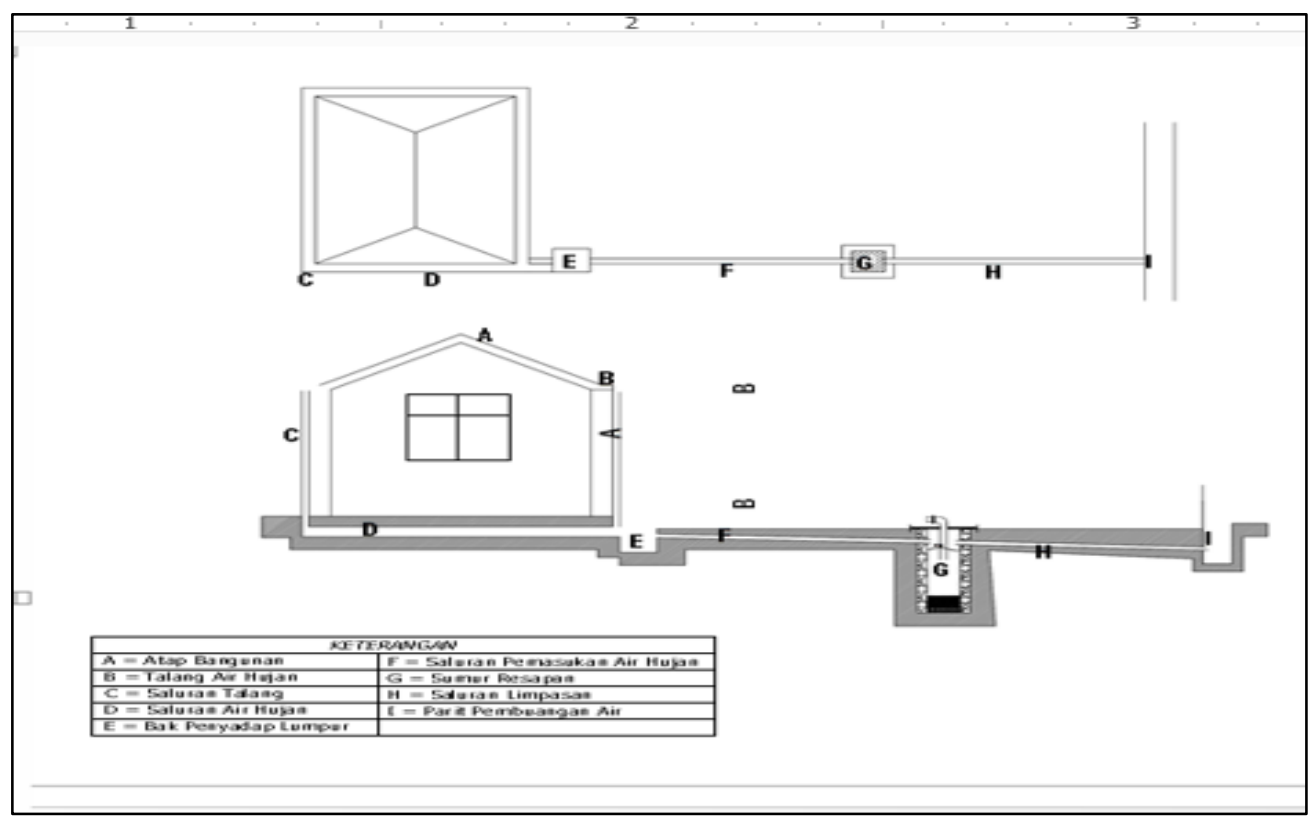

Gambar 2. Denah Lokasi Sumur Resapan di Lokasi Penelitian

Gambar berikut merupakan gambar detail sumur resapan berdasarkan hasil penelitian.

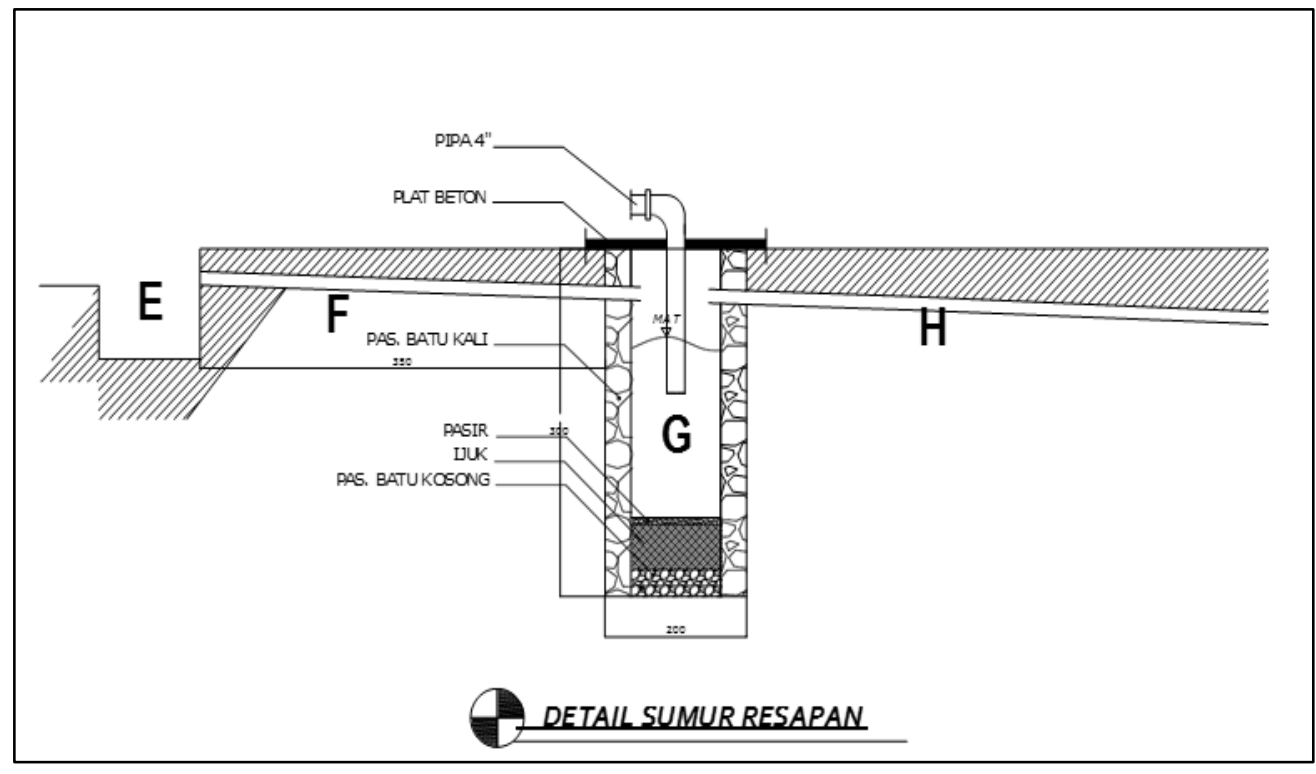

Gambar 3. Ditail Sumur Resapan Berdasarkan Hasil Penelitian

\section{KESIMPULAN}

Berdasarkan hasil perhitungan yang telah dilakukan, maka dapat disimpulkan beberapa hal antara lain :

a) Besarnya debit yang akan diresapkan untuk mengurangi limpasan permukaan adalah : untuk rumah type 36/90 dengan jumlah penghuni 5 orang, maka debit yang diresapkan $0.000581488 \mathrm{~m}^{3} /$ detik dan untuk rumah type $45 / 90$ dengan jumlah penghuni 5 orang, debit yang diresapkan adalah $0.000725558 \mathrm{~m}^{3} /$ detik. 
b) Analisa debit input dari sumur resapan, diperoleh kedalaman sumur untuk rumah type 36/90 kedalaman sumurnya $1 \mathrm{~m}$ dan kedalaman sumur untuk rumah type 45/90 kedalaman sumurnya $1 \mathrm{~m}$.

\section{DAFTAR PUSTAKA}

Bonnier . (1980). Probability Distribution and Probabilty Analysis, DPMA, Bandung.

Das,B.M..(1985). Mekanika Tanah (Prinsi-prinsip Rekayasa Geoteknis). Jakarta: Penerbit Erlangga.

Br.Sri Harto. (1993).Analisis Hidrologi. Jakarta: Gramedia Pustaka Utama.

Hindarko,S. (2002). Drainase Kawasan Daerah, Jakarta: Penerbit Esha.

Nurroh S, dkk. .(2009).. Pengaruh Sumur Resapan Terhadap Sistem Hidrologi dan Aplikasinya Terhadap Pemukiman di Jakarta Barat, Jurnal Fakultas Kehutanan Institut Pertanian Bogor, Bogor

SiswantoJ. (2001). Sistem Drainase Resapan untuk Meningkatkan Pengisian (Recharge) Air Tanah, Jurnal Natur Indonesia III (2). Semarang

SNI No. 03-2453-2002. Tata Cara Perencanaan Sumur Resapan Air Hujan untuk Lahan Perkarangan. Jakarta: Badan Standarisasi Nasional.

Soemarto,C.D. (1987). Hidrologi Teknik. Surabaya: Penerbit Usaha Nasional,.

Soewarno. (1991). Hidrologi Jilid. Bandung: Penerbit NOVA.

Sunjoto. (1988). Aliran Bawah Permukaan. Yogyakarta: PAU Ulmu Teknik UGM.

Suripin, M.Eng.Dr.Ir. (2004). Sistem Drainase Perkotaan yang Berkelanjutan. Yogyakarta: Penerbit Andi.

Triatmojo, Bambang. (1993). Hidraulika II. Yogyakarta: Beta Offset.

Verruijt, A. (1970).Theory of Groundwater Flow. London: Macmillan and Co Ltd. 